\title{
36. SECONDARY MINERALS OF DEUTERIC AND DIAGENETIC ORIGIN FILLING VOIDS AND ENCRUSTING SURFACES ON BASALTS FROM DEEP SEA DRILLING PROJECT LEG 54
}

\author{
William J. Furbish, Department of Geology, Duke University, Durham, North Carolina \\ and \\ Ed L. Schrader, Department of Geology and Geography, University of Alabama, University, Alabama
}

\begin{abstract}
A variety of secondary minerals, formed in response to different oxidation and hydration states, are found in vugs and on fracture surfaces of the basalt cores from DSDP Leg 54. The minerals are smectite (blue to grey), high-magnesium calcite, manganoan calcite, aragonite, iron oxides, phillipsite, todorokite, marcasite, and hydrobiotite. The relationship of the mineral assemblages to four depositional modes of the basalts are delineated. A definite sequence and genetic link exists between mineral type and host rock which is dependent upon the origin and subsequent cooling history of the basalt.
\end{abstract}

\section{INTRODUCTION}

Secondary minerals that fill (partially or completely) voids, encrust fracture surfaces, or fill fractures in the basalt retrieved from 10 drill holes of DSDP Leg 54 (Figure 1) were analyzed and compared (Table 1) in order to find possible correlations between secondary mineralogy and basalt depositional patterns.

On Leg 54, two major implacement or depositional patterns for the sampled basalts were found: (1) basalts were deposited in pre-existing ocean-floor basins as relatively undisturbed ponds (Sites: 422, 425, 427, and 428); and (2) basalts were deposited as thin flows and associated breccias on the flanks of spreading centers (Sites: 420, 421, 423, 424, and 429) (See Site Reports, this volume). Superimposed upon these two depositional patterns were such further variations as: apparent intercalation of flows and sediments (Site 422); flows with possible doleritic interlayered intrusions (Site 424); high-heat-flow areas, including supposed geothermal mounds (Sites 424 and 425); single units (Site 427) or layered units of variable thickness (Hole 428A).

The major thrust of this report is not an attempt to define mineralogy or mineral chemistry but rather to determine a possible correlation between secondary mineralogy and sequences of depositional and post-depositional events.

Information used in this report is confined to and defined by the available samples which in turn are correlated with shipboard descriptions and information. We emphasize that the basalts cored during Leg 54 are fresh, or only slightly altered. This study focuses on the secondary mineralogy of these slightly altered basalts, and speculates on the origin of these minerals.

\section{METHODS}

Standard petrographic and X-ray diffraction methods were used for mineral identification, while atomic absorption spectrophotometry and wet-chemical analysis defined the necessary mineral chemical parameters. Both petrographic and scanning electron microscope data were used extensively to delineate and record surface morphology and mineralogical association.

\section{SITES OF FORMATION FOR SECONDARY MINERALS}

Four types of possible sites for the deposition of secondary minerals in the Leg 54 basalt were delineated:

Irregular, Primary Cavities: Irregular shaped cavities exist in many areas of the host basalt where diktytaxitic textures are present. These cavities range from submicroscopic to $2 \mathrm{~mm}$ in dimension. They generally occur alone but may accompany vesicles. Some basalt flows with diktytaxitic texture do not contain cavities.

Vesicles: Occurring as either spheroidal or elongate forms, vesicles vary in size from submicroscopic to 2 $\mathrm{mm}$ in mean diameter. They range from absent to one fourth the volume of the basalt host.

Interconnecting porosity between vesicles and the longer "irregular cavities", is common. Porosity may be present in the host material, however, as indicated by alteration of primary silicate minerals and glasses, and deposition of secondary minerals in the vugs.

Fractures: Generated by cooling contraction and by tectonic movements, fractures were prevalent in many of the basaltic units. Fracture density varied among the sampled basalts as well as among the individual samples of the same type basalt. Contraction fractures were con- 


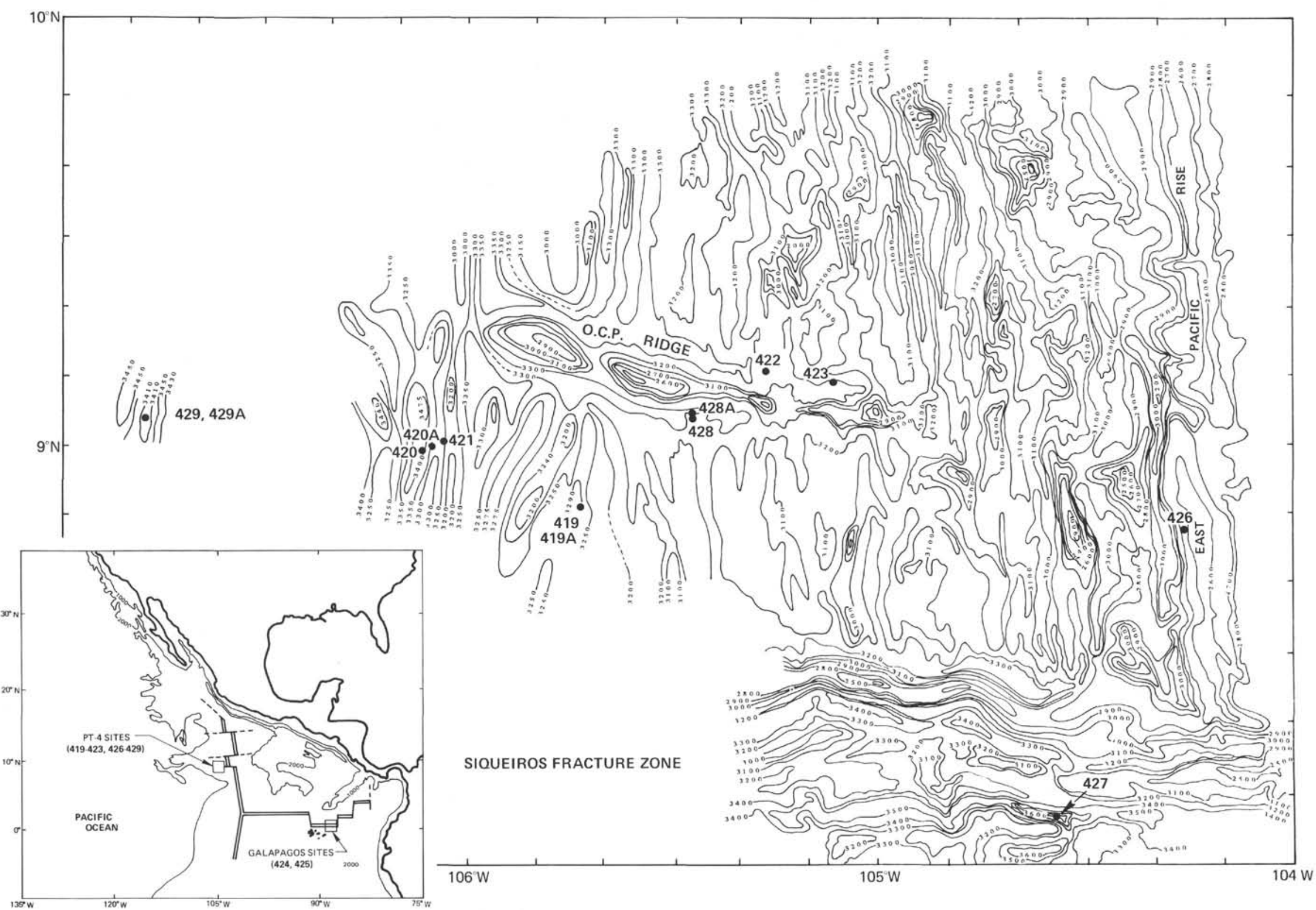

Figure 1. Location map showing position of DSDP Leg 54 drill sites. 
TABLE 1

Minerals Found in Vesicles and Fractures From Leg 54 Basalts

\begin{tabular}{|c|c|c|c|c|c|c|}
\hline $\begin{array}{c}\text { Core-Section } \\
\text { (Piece Number) }\end{array}$ & Smectite & & Calcite & Aragonite & Oxide & Miscellaneous \\
\hline $\begin{array}{l}\text { Hole } 420 \\
13, C C(2 A) \\
14-1(2) \\
15-1(5) \\
15-1(7)\end{array}$ & $\begin{array}{l}\text { v gr-ta } \\
\text { y bl-gr-ye } \\
\text { v bl } \\
\text { v gr-ye }\end{array}$ & & & & $\begin{array}{l}\mathrm{v} F \mathrm{Fe} \\
\mathrm{Fe} f \\
\mathrm{Fe} f \\
\mathrm{Fe} f\end{array}$ & Phillipsite $f$ \\
\hline $\begin{array}{l}\text { Hole } 421 \\
2-1(2) \\
3-1(1) \\
3-1(5) \\
3-1(18) \\
3-1 \text { (1) }\end{array}$ & $\begin{array}{l}\mathrm{v} \text { bl-wh } \\
\text { bl } \\
\text { v } \mathrm{gr} \\
\mathrm{v} \text { gr } \\
\mathrm{v} \text { gr-gy }\end{array}$ & f & & & $\begin{array}{l}\mathrm{Fe} f \\
\mathrm{Fe} f \\
\mathrm{Fe} f \\
\mathrm{v} \mathrm{Fe}\end{array}$ & $\begin{array}{l}\text { Phillipsite f } \\
\text { Phillipsite f } \\
\text { Phillipsite f }\end{array}$ \\
\hline $\begin{array}{l}\text { Hole 422 } \\
9-1(4 \mathrm{~B}) \\
9-2(5 \mathrm{C}) \\
9-4(7) \\
9-4(11) \\
9-4(12)\end{array}$ & 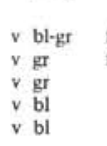 & $\begin{array}{l}f \\
f\end{array}$ & $\begin{array}{lll} & \\
\text { v } & \mathrm{HiMg} \\
\text { v } & \mathrm{HiMg} \\
\text { v } & \mathrm{HiMg}\end{array}$ & & & Phillipsite $f$ \\
\hline $\begin{array}{l}\text { Hole } 423 \\
5, \mathrm{CC}(4) \\
6-1(6)\end{array}$ & & & & & $\begin{array}{l}\text { Fe f } \\
\text { Fe f }\end{array}$ & \\
\hline $\begin{array}{l}\text { Hole 424 } \\
1-1(6) \\
S-2(4) \\
5-3(4) \\
S-3(10)\end{array}$ & $\begin{array}{l}\mathrm{v} \mathrm{bl-gr} \\
\mathrm{v} \text { bl } \\
\mathrm{v} \\
\mathrm{v}\end{array}$ & & & $\mathrm{v}$ & $\operatorname{Mn} \mathrm{f}$ & \\
\hline $\begin{array}{l}\text { Hole } 425 \\
9-2(3) \\
9-2(9)\end{array}$ & $\begin{array}{l}\mathrm{gr} \\
\mathrm{gr}\end{array}$ & ${ }^{f}$ & & f & Mn-Fe f & \\
\hline $\begin{array}{l}\text { Hole 427 } \\
9-1(6) \\
9-2(2) \\
9-2(4) \\
9-2(6) \\
9-2(7) \\
9-2(11 B) \\
9-2(14) \\
9-3(4) \\
9-5(3)\end{array}$ & $\begin{array}{l}\text { v gr } \\
\text { v } g r \\
\text { v gr } \\
\text { v gr } \\
\text { v gr } \\
\text { v gy-ta } \\
\text { g g } \\
\text { v gy }\end{array}$ & & $\begin{array}{l}\text { v } \mathrm{HiMg} \\
\text { v } \mathrm{HiMg} \\
\text { v } \mathrm{HiMg} \\
\text { v } \mathrm{Mn} \\
\text { v } \mathrm{HiMg}\end{array}$ & $\begin{array}{l}f \\
f\end{array}$ & $\begin{array}{l}\text { v Quartz } \\
\text { Fe f }\end{array}$ & $\begin{array}{l}\text { v Hydrobiotite } \\
\text { v Hydrobiotite } \\
\text { v Marcasite }\end{array}$ \\
\hline $\begin{array}{l}\text { Hole } 428 \\
6-2(10)\end{array}$ & gy & $\mathrm{f}$ & & & $\mathrm{Mn}-\mathrm{Fe} \mathrm{f}$ & Todorotite $\mathrm{f}$ \\
\hline $\begin{array}{l}\text { Hole 428A } \\
1-1(11) \\
1-1(16)\end{array}$ & $\begin{array}{l}\text { v bl-gr } \\
\text { v bl-gr-ye } \\
\text { ta-gy }\end{array}$ & & v HiMg & & & \\
\hline $\begin{array}{l}6-1(3) \\
7-1(1)\end{array}$ & $\begin{array}{l}\text { v bl-ye } \\
\text { ye-wh }\end{array}$ & & & $\mathrm{v}$ & $\underset{\mathrm{Fe}}{\mathrm{v}}$ & \\
\hline $\begin{array}{l}\text { Hole 429A } \\
2-1(5) \\
2-1(4 \mathrm{~B}) \\
2-1(7)\end{array}$ & $\begin{array}{l}g \mathrm{gr} \\
\mathrm{gr} \\
\text { ta-gy }\end{array}$ & $\begin{array}{l}f \\
f\end{array}$ & $\mathrm{HiMg}_{\mathrm{f}} \stackrel{\mathrm{f}}{\mathrm{f}}$ & & $v \mathrm{Fe}$ & $\begin{array}{l}\text { Phillipsite f } \\
\text { Phillipsite f }\end{array}$ \\
\hline
\end{tabular}

Note: $g r=g r e e n, b l=b l u e, g y=g r a y, y e=y e l l o w, t a=t a n, w h=w h i t e, v=v e s i c l e$, and $f=$ fracture. $\mathrm{HiMg}=\mathrm{High}$-magnesium calcite.

fined to shallow exterior glassy zones, while tectonically induced fractures crosscut all units to depth. Most tectonically induced fractures were interconnected.

External Surfaces: The exterior of flows and pillows presented a surface on which reaction could take place and secondary minerals form. Availability of these reaction surfaces to migrating solutions was dependent upon degree of sealing by subsequent flows and sediment cover.

The latter two types of depositional sites described above, unlike the first two, are interrelated and, therefore, permit solution passage directly between, through, and along them. If fractures intersect vugs, the vugs then become part of the fracture system and subsequent secondary mineral deposition follows as it would in an open-fracture system.

\section{SECONDARY MINERALIZATION}

\section{Mineralogy}

Secondary mineralization follows from and is characteristic of the above four types of depositional sites, as discussed in the previous section. The minerals fall into categories outlined by their origin or subsequent alteration.

Deuteric Minerals: Minerals of deuteric origin are the direct result of crystallization from residual magmatic fluids. They consist predominantly of dark green or blue smectites (with $\mathrm{Fe}^{+2}$ reduced iron) but also include biotite and chlorite that are deposited in vesicles or vugs and on small fracture surfaces (Table 1). Bass (1976) indicated similar relationships among Leg 34 basalts.

Hydrothermal Minerals: Following deposition of minerals of deuteric origin are minerals formed by hydrothermal processes: those that form either in equilibrium with oxidation-hydration processes or those that form by alteration of pre-existing minerals through the effects of oxidation-hydration. Calcite, quartz, sulfides, secondary smectites, and oxyhydroxides all may occur as hydrothermal phases (see Schrader et al., this volume).

Oxide Minerals and Oxidative Changes: The oxidation-hydration process can be considered as being either early or advanced. It may occur as a deuteric/hydrothermal process or be due to reaction with more oxidizing sea water, connate water, or other fluids. The process results in color changes of pre-existing minerals that are diagnostic of and dependent upon transformation from the ferrous to the ferric state. The change may take place as a simple color change (from green, blue, or gray to yellow or brown) in the pre-existing mineral or may take the formation of discrete particulate units of hematite or limonite.

\section{Effects of Depositional Sites on Mineralogy}

Cavities in basalt with diktytaxitic texture reflect their hosts' texture by their irregular outline and feldspar laths that project into the cavities. These voids appear to be impervious to solutions from which are deposited secondary minerals unless they are transected by fractures. Many of them are, however, lined with a thin layer of dark to light blue dendritic smectite or occasionally with thin layers of chlorite or biotite. The uniformity of amount with which the smectite occurs would indicate deposition by deuteric action.

Subsequent deuteric processes may leave calcite on a few of the cavity walls which, in turn, may be overlain by a layer of green to gray smectite.

Vesicles in the basalt reflect the changes that occur during cooling history from unit to unit of their basaltic host. Their walls tend to be more pervious to invading solutions than the walls of the cavities of basalts with diktytaxitic texture as reflected by the ratio of subsequent mineral fill. The vesicles, like the cavities of the diktytaxitic textured basalt, can be thinly lined with blue smectite of probable deuteric origin. They may also be empty but more generally are filled-completely or partially - with a more complex group of deuteric, secondary, or secondary alteration product, minerals (Table $1)$.

Green smectite linings or fillings predominate as the mineral of deuteric origin in the vesicles. The color may change to light green or to a tan-yellow color with an in- 
crease in oxygen as it becomes available to the initially dark green smectite (Table 1). This color change might also be the result of a change in the $\mathrm{Fe} / \mathrm{Mg}$ ratio in the depositing media. Other minerals of secondary depositional processes in the vesicles may include high-magnesium calcite, aragonite, phillipsite, todorokite, and gray chlorite-smectite.

Fractures in the basalt can be either isolated or interconnected with each other or with the host units' surface or interface. Because fractures can be isolated, they can carry secondary mineral products such as gray smectite, aragonite, and calcite. However, oxidative processes were seen to occur most frequently along fractures, and the resulting mineral assemblages reflect this fact. Under these conditions the minerals are iron oxide-hydroxides, magnesium-poor calcite, phillipsite, and some smectite associated with amorphous iron-manganese oxide/hydroxides (Table 1).

Depositional surfaces, such as the interface between sea water and basalt, that occur between flows or pillows represent the fourth mode where secondary minerals may form or be deposited. Because of the nature of their position relative to surrounding sea water, the resulting secondary minerals are predominantly of the advanced oxidative type. The minerals characteristically found are phillipsite in the altered surface rind, goethite, and noncrystalline manganese oxide/hydroxide. This may be modified or restricted by later sediment cover or subsequent flows.

\section{CORRELATIONS}

\section{Ponded Basalts of Site 427}

Site 427 was cored in the deepest-known trough of the Siqueiros fracture zone. It appears to represent a single cooling unit with quench zones at top and bottom as indicated from grain size. Horizontal parting or jointing exists throughout the recovered basalt cores, while vertical jointing is only pronounced in Core 427-10 (See Site Reports, this volume).

The general progression of secondary mineralogy downhole reflects an ideal sequence with respect to both unit cooling and formation of minerals that fall under the classification of either deuteric or early oxidative. No (or few) instances of overprint by advanced oxidative mineralogy are observed in the sequence.

In the fine-grained upper portion of the basalt unit a few pin-hole-sized vesicles occur. They may be empty or partly filled, but generally they are totally filled with a dark green smectite. Associated with, but later than, these vesicles are microfractures that may contain aragonite, smectite, biotite, or a combination of these minerals.

The microfractures are not confined to the upper portion of the unit but occur throughout it. Aragonite occurs in the fractures as radiating rosettes on the surfaces or as partial or total fill. No subsequent evidence of the hydrothermal or oxidative process is evident in change of either the associated biotite or smectite.

Quartz centers occur in a few of the vesicles in the upper, fine-grained part of the unit. This enigmatic situation is not unique to Leg 54 basalts; the origin of the quartz, nevertheless, is unknown. Sea-floor basalts do not usually contain quartz, and if they do the mineral is further associated with (but formed later than) smectites whose silica saturation is similar to that of the host basalt. Silica mobility during alteration of the basalts (Humphris and Thompson, this volume; Humphris and Thompson, 1978) might be an explanation but would as easily contribute to the further formation of smectites or talc instead of quartz. Limitations on either the host rock content or physicochemical condition of the formation of these silica-rich phases must, therefore, be factors in the formation of quartz.

Humphris and Thompson (1978) report that silica is generally leached from basalt and mobilized during hydrothermal alteration by sea water. A considerable portion of this silica is redistributed within the host rock as quartz in veins and vesicles. Their dredge samples showed relatively fresh cores with hydrothermally altered outer rims. No evidence of burial metamorphism was present.

Quartz, however, is a scarce component in most unmetamorphosed basalts, and the Leg 54 basalts are no exception. Bass (1976) has pointed out that where free silica is present in the absence of other silicates (such as smectite, celadonite, and talc) quartz can form. Or, conversely, if more free silica is available than is needed by smectite, then celadonite and talc can form. The lack of talc in the secondary mineral assemblage of Leg 54 basalts might, therefore, define limits on the silica supply of these rocks.

At the transition between fine- and medium-grained basalts of the Site 427 flow unit, there is a general enlargement of vesicle size and concomitant change in mineralogy to include high-magnesium calcite as a vesicle filling. This situation continues through the unit to the lower selvage, where small grain size and calcite-free vesicles again predominate.

In the central portion of the unit the vesicles are either empty or lined with single layers of dark green smectite, biotite, or both. If calcite is present, it may have been deposited after one or both clay minerals or be coated by them. Plate 1, Figure 1 illustrates a vesicle where high-magnesium calcite formed directly on the vesicle wall and was overlain by a layer of arborescent green-gray smectite. Plate 1, Figure 2 shows phillipsite coated with smectite. This is an example of phillipsite formed under early oxidative conditions. Smectites may have a flat, botryoidal, or arborescent surface configuration, and all types may occur in vesicles in close proximity to each other.

Two exceptions to normal mineralogy occur near the middle of the thick Site 427 flow unit. Here, a few vesicles contained stacked platelets and botryoidal forms of manganoan calcite, instead of high-magnesium calcite, and it, in turn, was overlain by a manganese oxide/hydroxide species (Plate 1, Figures 3 and 4). Certainly a local variation in the $\mathrm{Mg} / \mathrm{Mn}$ ratios must have existed for manganoan calcite to have been deposited rather than the high-magnesium species. Later overlay of a manganese oxide-hydroxide might reflect the change in $\mathrm{O}_{2} / \mathrm{CO}_{2}$ ratios within the vesicle as crystallization proceeded. 
In the same zone, high-magnesium calcite partly filled some of the vesicles. The surfaces of some calcite crystals were in turn overgrown or sprinkled with marcasite crystals. This occurrence raises two problems. What were the conditions-expecially of $p \mathrm{H}-$ for deposition of marcasite, and how was sulfur mobilized to form it?

The fact that crystal surfaces of calcite and areas surrounding marcasite in direct contact with calcite are etched indicates that conditions became more acid after deposition of the calcite, allowing marcasite to form.

From sulfur isotope studies, Field et al. (1976) gave two explanations for the presence of sulfur in pyrite of assumed hydrothermal origin from ocean-floor basalts. They were that the sulfur came from either a finite reservoir of deep-seated magmatic sulfur or from an infinite reservoir of heavy sea-water sulfur. Although sulfides occur throughout the basalt of Site 427 , their occurrence is only sporadic. This sporadic occurrence, their low abundance, and the isolated instance of marcasite deposition indicate local systems for derivation of sulfur from the host as well as a minimal transport distance.

No overriding advanced oxidative overprint was found to exist in basalts of Site 427. Because of this and the fact that the basalts apparently formed one cooling unit, the site can serve as a general model for secondary mineral deposition. The following examples are much less simple in their patterns.

\section{Ponded Basalts of Site $\mathbf{4 2 8}$}

Hole 428A was located in a topographic low south of the OCP Ridge in the transition zone between oceanic crust with a normal fabric, and the transverse ridge system. Petrographic data indicate that the basalts here represent several cooling units, all of which bear olivine. The lowest and thickest cooling unit (Cores 428A-3 through 7) is olivine-free.

The general progression of mineralization downhole reveals a more complex alteration history than that of the previously described Site 427 basalts. Diktytaxitic textures and resultant irregularly shaped vugs prevail throughout the basalt of both the olivine-bearing and olivine-free intervals. Spherical vesicles are also present, intermingled with the vugs. Weathering rinds occur on both fracture surfaces and on glassy selvages.

The secondary deuteric and diagenetic minerals in vugs and vesicles of the topmost flow unit of this sequence were formed by non-oxidative processes. Oxidative modification of these minerals has not occurred, even though the unit may have had a long exposure to sea water. Vesicles, of elongate configuration near the surface or oval near the base, occur throughout the unit. Irregular vugs in the diktytaxitic textured host occur throughout the unit but become more plentiful and larger near the base.

The vesicles may be empty, have a thin lining of dark green or dark blue smectite, or they may be completely filled with high-magnesium calcite within the smectite envelope. The irregular vugs also have a lining of green to blue-green smectite, and a few of them contain botryoidal calcite overgrowths on the smectite layer. Frac- tures within this unit may also contain a layer of blue clay on their surfaces. The whole unit represents a secondary mineral content of either deuteric or early diagenetic secondary mineral sequence. Practically no oxidative overprint is present, even though fractures exist and the unit is presently closest to the water/sediment interface.

The basalt cooling unit that lies directly below this has a wholly different character. A few small vesicles in this unit are either empty, coated internally with a thin layer of dark green smectite, or have a second layer within the first of a lighter green clay. Numerous irregularly shaped vugs resulting from the dyktytaxitic texture of the host give the basalt a scoriaceous appearance. They may be up to $3 \mathrm{~mm}$ in dimension, and may be empty, have an internal coating of yellow to yellow green smectite, or they may be totally filled with a dark green smectite that has a yellow-green reaction envelope.

An overprint of changing depositional conditions is evident in the color change that occurs on the inside of unfilled openings and on the outside of totally filled openings. Although an increase in oxygen is no doubt responsible for this change, it cannot be called an advanced oxidative process. These features of the secondary mineralogy distinguish this basalt unit from the above.

The lower interval at this site, an olivine-free basalt flow or sill, also contains basalts that can be distinguished on the basis of their secondary deuteric or diagenetic mineral content.

One portion of this unit is marked by irregular vugs that contain in inward sequence: (1) a blue smectite lining, (2) a yellow-tan smectite with an aragonite or blue smectite lining, (3) a yellow-tan smectite in which various manganese oxide-hydroxides were simultaneously deposited. This unit sequence indicates that changes in oxygen fugacity occurred, but it does not imply that an overprint of truly oxidative processes took place.

A portion of this interval, however, shows the effects of oxidative processes. There are irregular vugs which contain only a yellow clay, and iron oxide-hydroxide is prevalent in veins and replaces minerals throughout the host rock. Thus, this massive unit was definitely subjected to oxidative processes before subsequent basalt deposition. It might reflect a long period of exposure to sea water before it was covered, as well as extrusive conditions (brecciated pillow lavas) conducive to intimate contact with sea water.

It would appear from the above discussion that, where the individual flow units are deposited as ponds and not subjected to brecciation by offridge movement that the various basaltic units have different histories of formation of secondary minerals of deuteric and diagenetic origin.

\section{Thin Flows of Site $\mathbf{4 2 1}$}

Site 421 is located $200 \mathrm{~km}$ west of the East Pacific Rise crest, and the cores from it contain predominantly aphyric basalt and glass. Shipboard descriptions (See Site Report, this volume) indicate that it consists of 
well-jointed sheet flows or pillow basalts. Glass selvages and/or weathering rinds are present on many of the recovered rock samples.

Only a very few small vesicles are present throughout the section. They are either empty or are lined or filled with blue to blue-green smectite. Subsequent oxidation processes may alter the clay to a lighter color or include iron oxide/hydroxide if they occur near a fracture surface. Where the basalt is fine-grained, oxidation of iron was confined to within a few millimeters of the fracture surface. In coarse-grained basalt, however, it can penetrate the whole sample.

Fracture surfaces (many in glass selvages) reflect very well the ongoing alteration and mineral deposition that have occurred since extrusion.

Remnants of blue to blue-green smectite may remain on some fracture surface areas. Most, however, is now a white or gray in color because of alteration. Phillipsite crystals may have grown directly on the green clay. It may also lie directly on an irregular altered fracture surface on the host basalt.

Some secondary minerals of deuteric or non-oxidative deposition may remain in the vesicles and on fracture surfaces where the basalt host is fine-grained, but there is nevertheless a very strong overprint of purely oxidative processes in the basalts of Site 421 .

Magnesium-poor calcite has developed from aragonite on fracture surfaces, and goethite (associated with noncrystalline manganese oxide/hydroxide patches in some large fractures near the tops of cooling units) and phillipsite (associated with altered smectites along basalt fracture surfaces) are common.

\section{Thin Flows of Hole 424}

Hole 424 was one of a north-south transect of four holes drilled into a supposed geothermal mound field located about $22 \mathrm{~km}$ south of the Galapagos spreading center. It was drilled at the apparent apex of an assumed geothermal mound and penetrated at least three cooling units of massive flows. These were subdivided into zones of varying degrees of crystallinity.

A few small vesicles lined with blue or blue-green smectites are present throughout the whole section. Some irregular vugs in diktytaxitic textured basalt occur and are lined with blue or blue-green smectites. Aragonite spheres formed over clay were found in one irregu- lar vug in Section 424-5-3 (Plate 2, Figures 1 and 2). Blue to blue-green clays are also present on minute fractures.

These basalts have only deuteric and early oxidative secondary minerals. There is no major fracturing. Even though glassy areas were present, oxidative processes were noted only as rind alteration at the base of Section 424-4-6 (Plate 2, Figures 3 and 4).

This was unexpected for basalts in a high-heat-flow geothermal field. Lack of fracturing, secondary oxidative mineralization, or rock alteration indicates that either the core penetrated well away from a geothermal vent or that no geothermal vent exists in the immediate area.

\section{CONCLUSIONS}

In conjunction with data from petrologic studies and core descriptions, the study of secondary minerals deposited in vugs and fractures of Leg 54 basalts leads to inferences about their cooling history and their exposure to sea water or trapped or circulating formation fluids.

Generally single flows, flow series, pillows, and rubble have different deuteric, early or advanced oxidative secondary mineral sequences.

No evidence for the presence of hydrothermal vents exists in the basalt core from Hole 424, which was drilled directly into the apex of a supposed hydrothermal mound. Either no vents existed in the general area where the drill penetrated, or vents are very small and the hole was drilled well away from them.

\section{REFERENCES}

Bass, M. N., 1976. Secondary minerals in oceanic basalt, with special reference to Leg 34, Deep Sea Drilling Project. In Yeats, R. S., Hart, S. R., et al., Initial Reports of the Deep Sea Drilling Project, v. 34: Washington (U.S. Government Printing Office), pp. 393-432.

Field, C. W., Dymond, J. R., Ross Heath, G., Corliss, J. B., and Dasch, E. J., 1976. Sulfur isotope reconnaissance of epigenetic pyrite in ocean-floor basalts, Leg 34 and elsewhere. In Yeats, R. S., Hart, S. R., et al., Initial Reports of the Deep Sea Drilling Project, v. 34: Washington (U.S. Government Printing Office), pp. 381-384.

Humphris, S. E., and Thompson, G., 1978. Hydrothermal alteration of oceanic basalts by seawater. Geochim. Cosmochim. Acta, v. 42, pp. 107-125. 



\section{PLATE 1}

Figure 1 Section 427-9-2. SEM of high-magnesian calcite, partly covered with vermicular smectite forms in a vesicle. Bar scale $=100 \mu \mathrm{m}$.

Figure 2 Section 427-9-2. SEM of smectite coating on phillipsite. Bar scale $=100 \mu \mathrm{m}$.

Figure 3 Section 427-9-2. SEM of a botryoidal crust of manganoan calcite on a vesicle wall. Bar scale $=$ $100 \mu \mathrm{m}$.

Figure 4 Section 427-9-2. SEM enlargement of Plate 1, Figure 3. Bar scale $=2 \mu \mathrm{m}$. 
PLATE 1
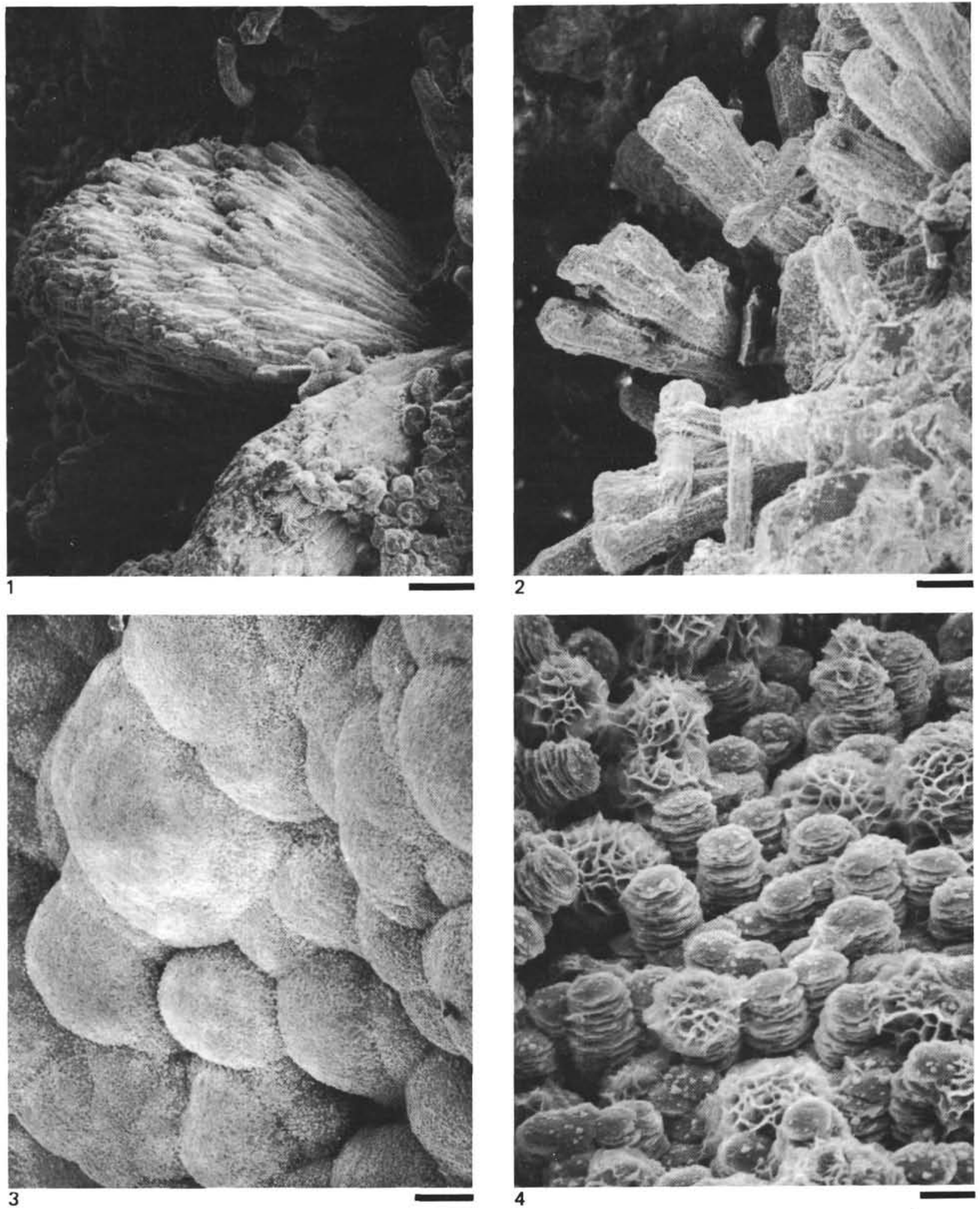


\section{PLATE 2}

Figure 1 Section 424-5-3. SEM of a spherical crystal growth of aragonite on a vesicle wall. Bar scale $=400 \mu \mathrm{m}$.

Figure 2 Section 424-5-3. SEM enlargement of Plate 2, Figure 1. Bar scale $=10 \mu \mathrm{m}$.

Figure 3 Section 424-4-6. SEM of apparently amorphous manganese oxide on fracture surface. Bar scale = $100 \mu \mathrm{m}$.

Figure 4 Section 424-4-6. SEM enlargement of Plate 2, Figure 3. Bar scale $=2 \mu \mathrm{m}$. 
PLATE 2
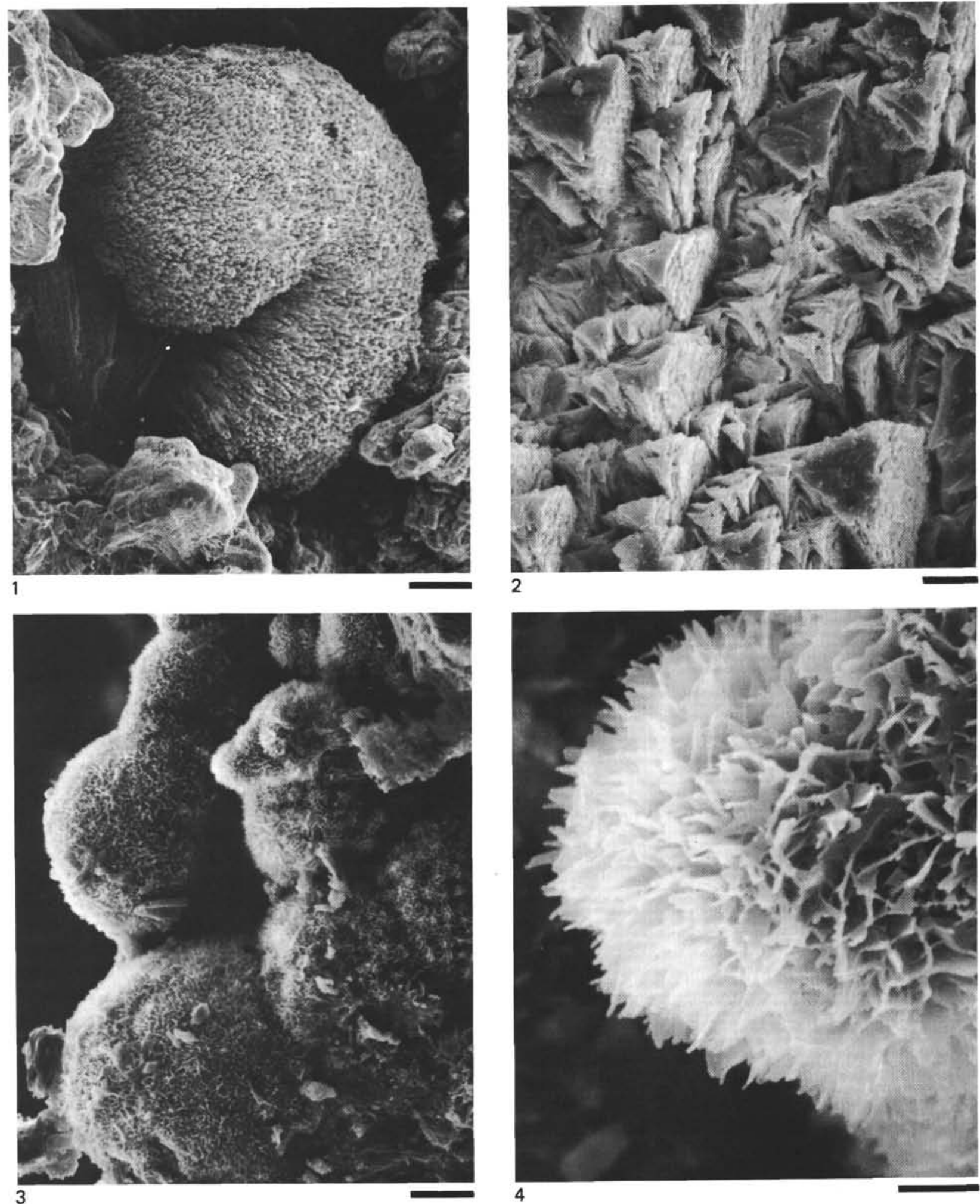